\title{
OPEN Effect of bentonite as a soil amendment on field water-holding capacity, and millet photosynthesis and grain quality
}

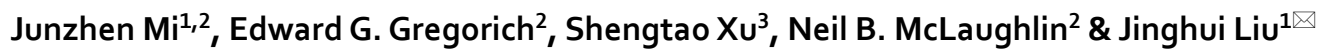

\begin{abstract}
A field experiment was conducted in a semi-arid region in northern China to evaluate the effects of bentonite soil amendment on field water-holding capacity, plant available water, and crop photosynthesis and grain quality parameters for millet [Setaria italic (L.) Beauv.] production over a 5 -year period. Treatments included six rates of bentonite amendments $(0,6,12,18,24$ and $\left.30 \mathrm{Mg} \mathrm{ha}^{-1}\right)$ applied only once in 2011 . The application of bentonite significantly $(P<0.05)$ increased field water-holding capacity and plant available water in the $\mathbf{0 - 4 0} \mathrm{cm}$ layer. Bentonite also significantly $(P<0.05)$ increased the emergence rate, above-ground dry matter accumulation (AGDM), net photosynthesis rate (Pr), transpiration rate ( $\mathrm{Tr}$ ), soil and plant analysis development (SPAD) and leaf water use efficiency (WUE). It also increased grain quality parameters including grain protein, fat and fiber content. Averaged over all the years, the optimum rate of bentonite was $24 \mathrm{Mg} \mathrm{ha}^{-1}$ for all plant growth and photosynthesis parameters except for grain quality where $18 \mathrm{Mg} \mathrm{ha}^{-1}$ bentonite had the greatest effect. This study suggests that bentonite application in semi-arid regions would have beneficial effects on crop growth and soil water-holding properties.
\end{abstract}

Arable land is limited and loss of productivity by soil degradation poses a threat to food security in many areas. Environmental factors including moisture, temperature, soil quality and frost-free growing period, affect plant growing systems and crop yield, and play an important role in agriculture production ${ }^{1,2}$. Natural rainfall often cannot meet the crop requirements for water in arid and semi-arid regions ${ }^{3}$. Drought is one of the most critical factors affecting agricultural production in semi-arid rain-fed regions under a changing climate ${ }^{4}$. It is one of major factors influencing crop loss worldwide, reducing crop yields by up to $50 \%$ each year ${ }^{5,6}$. By 2050 climate change is estimated to lead to a global decline of crop production by $9 \%{ }^{7}$. In addition, drought events are predicted to become more frequent in the future with global warming ${ }^{8}$. Therefore, adopting appropriate approaches to reduce the adverse effects of climate change on agriculture production is a priority.

Dryland farming accounts for more than $70 \%$ of the total arable land in northern China; low rainfall and poor soil quality are major constraints to agriculture production in this region ${ }^{9}$. The region along the Great Wall in Inner Mongolia in northern China is a semi-arid area and is characterized by low soil water-holding capacity which leads to low water use efficiency for crops. Therefore, water saving innovations are required to alleviate drought stress for sustainable development of agriculture in the arid and semi-arid regions where water is the primary limiting factor for agriculture production.

Millet is one of the main cultivated crops in China and is distributed in the arid and semi-arid regions of all provinces of northern China ${ }^{10}$ with a planted area of $8.61 \times 10^{5}$ ha in $2017^{11}$. Virtually all millet production is rainfed and therefore drought is one of the most limiting factors. To cope with drought stress, different strategies including deficit irrigation, breeding new drought resistant plant varieties, and mulching are being practised $^{12-14}$. More effective strategies are needed for dealing with water shortages in arid and semi-arid regions because current water management strategies are not able to ensure sustainability of agriculture production in these regions. Application of soil amendments which increase soil water-holding capacity is one strategy that is receiving considerable attention in agriculture research.

\footnotetext{
${ }^{1}$ National Outstanding Agriculture Research Talents and Innovation Team, Inner Mongolia Agricultural University, Hohhot 010019, Inner Mongolia, China. ${ }^{2}$ Central Experimental Farm, Agriculture and Agri-Food Canada, Ottawa Research and Development Centre, Ottawa, ON K1A 0C6, Canada. ${ }^{3}$ Agricultural Environment and Resources Institute, Yunnan Academy of Agricultural Sciences, Kunming 650205, Yunnan, China.『email: cauljh@aliyun.com
} 


\begin{tabular}{|l|l|}
\hline Property & Value \\
\hline Texture & Sandy loam \\
\hline Sand content $(\%)$ & 72.8 \\
\hline Silt content $(\%)$ & 13.4 \\
\hline Clay content $(\%)$ & 13.8 \\
\hline Soil pH & 8.0 \\
\hline Soil cation exchange capacity $\left(\mathrm{cmol} \mathrm{kg}^{-1}\right)$ & 8.3 \\
\hline Soil bulk density $\left(\mathrm{g} \mathrm{cm}^{-3}\right)$ & 1.42 \\
\hline Soil organic matter $\left(\mathrm{g} \mathrm{kg}^{-1}\right)$ & 10.96 \\
\hline Total $\mathrm{N}\left(\mathrm{mg} \mathrm{kg}^{-1}\right)$ & 0.49 \\
\hline Total P $\left(\mathrm{mg} \mathrm{kg}^{-1}\right)$ & 0.43 \\
\hline
\end{tabular}

Table 1. Soil property data in the experimental site (data from Mi et al. ${ }^{31}$ ).

Photosynthesis characteristics play a fundamental role in physiological processes that affect plant carbon metabolism in cells and growth under harsh environmental conditions such as drought and heat ${ }^{15,16}$. Leaf structure and soil properties both affect photosynthesis, and drought decreases plant photosynthesis activity in leaves, and consequently, decreases crop growth and quality ${ }^{17}$. Addition of a superabsorbent polymer to soil has been shown to retain water and nutrients that are released slowly as required by crop growth, thereby improving soil physical, chemical and biological properties, and increasing soil productivity ${ }^{18,19}$. Studies have shown that application of these types of soil amendments can improve the available soil water-holding capacity, reduce the evapotranspiration, increase the water and fertilizer use efficiency in crops and increase crop emergence, growth and yield ${ }^{20,21}$. They also have been shown to have potential for improving crop photosynthesis characteristics in the field ${ }^{22}$. This is attributed to improvement in leaf stomatal conductance and $\mathrm{CO}_{2}$ assimilation rate by increased transpiration rate $^{23-25}$.

Bentonite is a natural soil amendment which is very abundant in China, with over $8.0 \mathrm{Pg}$ of proven reserves ${ }^{26}$. At present bentonite is widely used for adsorbing metal ions and dye, disposing radioactive wastes and purifying viral RNA and waste water due to its strong adsorption propertie ${ }^{27-30}$. Furthermore, its use as a soil amendment may be an effective approach for solving some of the agronomic/environmental problems related to drought stress and soil degradation in agricultural systems. In our previous paper, results showed that bentonite increased soil moisture and soil water storage, increased millet yield and improved water use efficiency ${ }^{31}$. Other research reported that clay as a soil amendment added to sandy soil can improve soil available water, soil organic carbon and soil potassium, and increase crop emergence and yield ${ }^{32}$. This was attributed to increase in soil aggregation which results in an improvement in soil porosity soil water-holding capacity, soil fertility and crop growth ${ }^{33}$. There are some studies on clay and polymer superabsorbent soil amendments used in agriculture, but little information is available about effects of bentonite as a soil amendment on crop photosynthesis characteristics and grain quality in agriculture production.

The objective of this study was to evaluate the effect of bentonite amendments on field water-holding capacity and plant available water in the $0-60 \mathrm{~cm}$ layer, emergence rate, above-ground dry matter accumulation, photosynthesis and grain quality parameters for millet production over five years in a semi-arid region. Preliminary data on a subset of the field measurements, emergence rate and above-ground dry matter accumulation were published for the first three years in the same field experiment in a Chinese journal and a non-peer reviewed conference proceedings ${ }^{34,35}$. The present paper covers a wider range of measurements including field waterholding capacity, plant available water, photosynthesis parameters and grain quality attributes to provide a more complete assessment of the research over five years. Meanwhile preliminary published data were cited to determine the changes in emergence rate and above-ground dry matter accumulation in the fourth and fifth year after application of bentonite.

\section{Materials and methods}

Experimental site and design. The field experiment was conducted from 2011 to 2015 in Yijianfang village $\left(111^{\circ} 39^{\prime} \mathrm{E}, 39^{\circ} 57^{\prime} \mathrm{N}\right)$ of Qingshuihe County, Hohhot, Inner Mongolia, China. Mean annual rainfall is $365 \mathrm{~mm}$ and mean annual potential evaporation is $2577 \mathrm{~mm}$. The experimental site is in the hilly gully region of the loess plateau in northeastern China, the soil genesis is loess, and the soil texture of the field is sandy loam. The initial soil chemical properties (Table 1) and climate data in the experimental site were provided in our previous paper $^{31}$.

The experimental design was a randomized complete block with three replicates and included six treatments. Each plot was $6 \mathrm{~m} \times 5 \mathrm{~m}$. The treatments consisted of six rates of bentonite: $0,6,12,18,24$ and $30 \mathrm{Mg} \mathrm{ha}^{-1}$. The bentonite was applied only one time in 2011 and was broadcast with fertilizer prior to seeding and mixed into the soil to depth of about $30 \mathrm{~cm}$ by cultivating. Tillage management included mouldboard plow followed by cultivating in the spring. Diammonium phosphate (DAP, 18-46-0) and urea (46-0-0) as starter fertilizer were applied each year at 225 and $75 \mathrm{~kg} \mathrm{ha}^{-1}$ respectively; additional urea was applied at $150 \mathrm{~kg} \mathrm{ha}^{-1}$ at approximately $60 \mathrm{~d}$ after sowing. 


\begin{tabular}{|l|l|l|l|l|l|l|l|}
\hline \multicolumn{7}{|c|}{ Bentonite composition (on a weight basis) and cost } \\
\hline $\mathrm{SiO}_{2}$ & $\mathrm{Al}_{2} \mathrm{O}_{3}$ & $\mathrm{Na}_{2} \mathrm{O}$ & $\mathrm{CaO}$ & $\mathrm{MgO}$ & $\mathrm{K}_{2} \mathrm{O}$ & $\mathrm{Fe}_{2} \mathrm{O}_{3}$ & Cost \\
\hline $73.20 \%$ & $11.40 \%$ & $0.31 \%$ & $2.67 \%$ & $1.05 \%$ & $2.58 \%$ & $0.29 \%$ & $63 \mathrm{USD} \mathrm{mg}^{-1}$ \\
\hline
\end{tabular}

Table 2. Bentonite composition and cos.

Bentonite composition and cost are given in Table $2 . \mathrm{K}_{2} \mathrm{O}$ was the only major plant nutrient in the bentonite. The soil was slightly alkaline, and the addition of $\mathrm{CaO}$ and $\mathrm{MgO}$ in the bentonite had only a small effect on the soil $\mathrm{pH}$ which ranged from $8.00-7.87$.

Millet (variety: No. 5 Zhang) was planted at the beginning of May and harvested in the middle of September in each year. The seeding depth was 3-5 cm, row spacing was $25 \mathrm{~cm}$, and planting density was $180,000-225,000$ plants $\mathrm{ha}^{-1}$. On the same day as millet planting in the spring, an additional 300 millet seeds were planted by hand between two rows in each plot for measurement of emergence rate (ER) after 30 days; the plants were later removed after emergence counts. At maturity, a $1 \mathrm{~m}^{2}$ area (four rows of $1 \mathrm{~m}$ length) from each plot was randomly selected and harvested by hand to measure millet yield.

Field and laboratory measurements. Duplicate undisturbed soil samples for field water-holding capacity were taken at depths of $0-10,10-20,20-40$ and $40-60 \mathrm{~cm}$ at $90 \mathrm{~d}$ after sowing by the cutting ring method $^{36}$ from 2013 to 2015 . Undisturbed soil samples in the cutting rings were placed in $4.0-4.8 \mathrm{~cm}$ of water until they were saturated. The second set of soil samples was air-dried, passed through 1-mm mesh screen and placed in rings of the same size. The rings with undisturbed saturated soil were covered and placed on top of the rings with air-dry soil for $8 \mathrm{~h}$. The rings with undisturbed soil were then taken to be at field capacity which was determined by oven drying a sub-sample.

Plant available water (PAW) from 2013 to 2015 was determined by field water-holding capacity (FC) and wilting point (WP) ( $1500 \mathrm{kPa}$ soil water tension). Plant available water was calculated by equation: $\mathrm{PAW}=\mathrm{FC}-\mathrm{WP}^{37}$.

Percent germination was determined in the laboratory by placing 100 millet seeds on a damp filter paper for 15 days at room temperature.

Above-ground dry matter accumulation (AGDM) of the millet plants was measured by gravimetric method at 50, 70, 90, 110 and $130 \mathrm{~d}$ after sowing to monitor the bentonite effect on plant growth over the growing season. Ten plants were retrieved from each plot and oven-dried at $105^{\circ} \mathrm{C}$ for $30 \mathrm{~min}$, and then at $75^{\circ} \mathrm{C}$ for $24 \mathrm{~h}$ until constant weight. The equivalent field area for the ten plants was $0.5 \mathrm{~m}^{2}$.

Net photosynthesis rate $(\mathrm{Pn})$ and transpiration rate (Tr) from 2013 to 2015 were measured at $90 \mathrm{~d}$ after planting with a Li 6400 portable photosynthesis system equipped with a $18 \mathrm{~cm}^{3}$ prismatic leaf chamber (Li 6400, Licor, Lincoln, NE, USA) as described in Arbona et al. ${ }^{22}$. Ten randomly selected flag leaves in each plot were measured. All the determinations were performed under the constant air flow rate $\left(500 \mu \mathrm{mol} \mathrm{s}{ }^{-1}\right)$, and conducted between 9:00-11:00 am when the temperature was $24 \pm 2{ }^{\circ} \mathrm{C}$ on a sunny day. Leaf water use efficiency (WUE) was calculated by equation: $\mathrm{WUE}=\mathrm{Pn} / \mathrm{Tr}$.

SPAD was measured at 90 days after planting (around heading stage) from 2013 to 2015 with a Soil and Plant Analysis Development meter (SPAD-502, Konica Minolta, Tokyo, Japan). It was also performed on ten (different) flag leaves per plot similar to those for the net photosynthesis rate measurements. Three positions selected per flag leaf were measured and then the average was calculated.

Mature millet seeds were ground into flour for measurement of total protein, fat and fiber from 2011 to 2015.

Total grain protein content was measured using the Kjeldahl method ${ }^{38,39}$. A 1.0 g sample was digested with $20 \mathrm{ml} \mathrm{H}_{2} \mathrm{SO}_{4}$ at $300^{\circ} \mathrm{C}$ until the digestate was clear. After cooling, $20 \mathrm{ml}$ distilled water was added, agitated, and then further diluted to $100 \mathrm{ml}$ with distilled water. Then a sample of $10 \mathrm{ml}$ of the solution was distilled with $10 \mathrm{ml}$ of $12 \% \mathrm{H}_{3} \mathrm{BO}_{3}$ and $10 \mathrm{ml}$ of $40 \% \mathrm{NaOH}$ solution for $7 \mathrm{~min}$, and titrated with $0.5 \mathrm{~N} \mathrm{HCl}$.

Total fat content in the grain was measured with a fat analyser using the Soxhlet extractor method ${ }^{40,41}$. A $3 \mathrm{~g}$ sample wrapped with filter paper was alternately steeped in the diethyl ether, and washed with water at $70-80{ }^{\circ} \mathrm{C}$ until no oil was visible in the wash water. After the diethyl ether was volatilized, the samples were dried under vacuum.

Total fiber content in the grain was measured with a gravimetric method ${ }^{42}$. After extracting total fat, a $1.0 \mathrm{~g}$ dried sample was extracted with $200 \mathrm{ml}$ of $1.25 \% \mathrm{H}_{2} \mathrm{SO}_{4}$ and $1.25 \% \mathrm{NaOH}$ solution at $100{ }^{\circ} \mathrm{C}$ for $1.5 \mathrm{~h}$. Samples were then steeped in acetone for $10 \mathrm{~min}$, oven-dried at $105^{\circ} \mathrm{C}$ until constant weight and then fired at $550{ }^{\circ} \mathrm{C}$ until constant weight.

The field water-holding capacity, plant available water, photosynthesis parameters were measured from 2013 to 2015 to determine their changes three to five years after the application of bentonite amendment. In this paper the last two-years of data on AGDM and ER are shown in Figs. 4 and 3; the data for the first three years were previously published ${ }^{34,35}$. We combined published preliminary data from the same experiment with the present data to determine the changes in AGDM and ER over the five years following the single application of bentonite amendment in 2011.

Data analysis. The FWC, PAW, ER, AGDM, SPAD, photosynthesis parameters (Tr, Pn, SPAD and WUE) and grain quality for each treatment were calculated by averaging three replicates for each plot, i.e. averaging subplot measurements. The normality and homogeneity of variances were checked using Shapiro-Wilk and Bartlett test before performing an analysis of variance (ANOVA). A two-way linear models ANOVA was performed 


\begin{tabular}{|c|c|c|c|c|c|c|c|c|c|}
\hline \multirow[b]{2}{*}{ Factors } & \multirow[b]{2}{*}{ DF } & \multicolumn{2}{|l|}{ Pn } & \multicolumn{2}{|l|}{$\mathrm{Tr}$} & \multicolumn{2}{|l|}{ SPAD } & \multicolumn{2}{|l|}{ WUE } \\
\hline & & F value & $P$ & F value & $P$ & F value & $P$ & F value & $P$ \\
\hline $\mathrm{T}$ & 5 & 135.97 & $<0.001^{* * *}$ & 11.19 & $<0.001^{\star * *}$ & 78.9 & $<0.001^{* * *}$ & 10.08 & $<0.001^{* * *}$ \\
\hline $\mathrm{Y}$ & 2 & 50.35 & $<0.001^{* * *}$ & 87.66 & $<0.001^{* * *}$ & \begin{tabular}{|l|}
95.09 \\
\end{tabular} & $<0.001^{* * *}$ & \begin{tabular}{|l|}
73.64 \\
\end{tabular} & $<0.001^{* * *}$ \\
\hline$T * Y$ & 10 & 7.65 & $<0.001^{\star * *}$ & 1.73 & NS & 2.38 & $0.014^{\star}$ & 0.47 & NS \\
\hline
\end{tabular}

Table 3. ANOVA of effect of bentonite treatments $(\mathrm{T})$ and year $(\mathrm{Y})$ on photosynthetic parameters. ${ }^{*}$ and

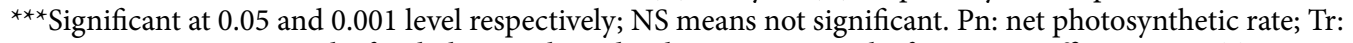
transpiration rate; SPAD: leaf soil plant analysis development; WUE: leaf water use efficiency. Pn, Tr, SPAD, and WUE were measured at $90 \mathrm{~d}$ after sowing over the last three years, 2013 to 2015.

\begin{tabular}{|c|c|c|c|c|c|c|c|c|c|c|c|}
\hline \multirow[b]{2}{*}{ Factors } & \multirow[b]{2}{*}{ DF } & \multicolumn{2}{|l|}{ Protein } & \multicolumn{2}{|l|}{ Fat } & \multicolumn{2}{|l|}{ Fiber } & \multicolumn{2}{|c|}{ Emergence } & \multicolumn{2}{|l|}{ AGDM } \\
\hline & & F value & $P$ & F value & $P$ & F value & $P$ & F value & $P$ & F value & $P$ \\
\hline $\mathrm{T}$ & 5 & 21.22 & $<0.001^{* * *}$ & 134.22 & $<0.001^{* * *}$ & 428.83 & $<0.001^{* * *}$ & 114.34 & $<0.001^{* * *}$ & 758.47 & $<0.001^{* * *}$ \\
\hline $\mathrm{D}$ & 4 & & & & & & & & & \begin{tabular}{|l|}
$45,034.1$ \\
\end{tabular} & $<0.001^{\star * *}$ \\
\hline $\mathrm{T}^{*} \mathrm{D}$ & 20 & & & & & & & & & 64.62 & $<0.001^{* * *}$ \\
\hline $\mathrm{Y}$ & 4 & 7.66 & $<0.001^{* * *}$ & 109.83 & $<0.001^{* * *}$ & 294.75 & $<0.001^{* * *}$ & 24.08 & $<0.001^{* * *}$ & 3786.67 & $<0.001^{* * *}$ \\
\hline $\mathrm{T}^{*} \mathrm{Y}$ & 20 & 0.41 & NS & 13.34 & $<0.001^{\star * *}$ & 43.95 & $<0.001^{* * *}$ & 3.75 & $<0.001^{\star * *}$ & 22.15 & $<0.001^{* * *}$ \\
\hline $\mathrm{Y}^{*} \mathrm{D}$ & 16 & & & & & & & & & 611.36 & $<0.001^{* * *}$ \\
\hline$T^{*} Y^{\star} D$ & 80 & & & & & & & & & 8.7 & $<0.001^{* * *}$ \\
\hline
\end{tabular}

Table 4. ANOVA of effect of bentonite treatments (T), day (D) and year (Y) on emergence rate, AGDM and grain quality parameters, protein, fat and fiber. ${ }^{\star * \star}$ Significant at 0.001 levels; NS means not significant. Protein, Fat, Fiber, Emergence and AGDM were measured over five years, 2011 to 2015.

to analyze the differences in Pn, Tr, SPAD, WUE, protein, fat, fiber, ER and AGDM among bentonite amendments. Statistical analyses were performed with SAS Ver. 9.3 software package for Windows (SAS Institute Inc., Cary, NC, USA). Differences among bentonite amendment means were determined using the linear model with Tukey's multiple comparisons at 5\% level. Pearson's correlations were performed to determine the relationships among all the parameters. Data were plotted using Sigmaplot 10.0 (Systat Software, Inc. San Jose, CA,USA).

\section{Results}

ANOVA of measured parameters. The ANOVA for different measurements (Tables 3 and 4 ) showed that bentonite treatment $(\mathrm{T})$, day $(\mathrm{D})$ and year $(\mathrm{Y})$ had a highly significant $(P<0.01)$ effect on emergence, AGDM, $\mathrm{Pn}, \mathrm{Tr}, \mathrm{SPAD}, \mathrm{WUE}$, protein, fat and fiber. The interaction of $\mathrm{T}^{\star} \mathrm{Y}$ had a significant $(P<0.05)$ effect on all of the measured parameters except Tr, WUE and protein. The interaction of $T^{\star} D, D^{\star} Y, T^{\star} Y$ and $T^{\star} D^{\star} Y$ had a highly significant $(P<0.01)$ effect on AGDM.

Field water holding capacity (FC). All bentonite amendments significantly $(P<0.05)$ increased the FC compared with control without bentonite at 0-40 soil layers except for $6 \mathrm{mg} \mathrm{ha}^{-1}$ at $0-10$ and $20-40 \mathrm{~cm}$ layers in 2013. None of the bentonite amendments had an effect at the 40-60 cm layer (Fig. 1). In 2013, 2014 and 2015, FC for bentonite treatments was significantly increased by up to $9 \%, 11 \%$ and $12 \%$, respectively. Improvements in FC for all bentonite treatments ranged from 1 to $9 \%$ for the $0-10 \mathrm{~cm}$ layer, from 1 to $12 \%$ for the $10-20 \mathrm{~cm}$ layer, and from 0 to $11 \%$ for the $20-40 \mathrm{~cm}$ layer. The effect of bentonite amendment addition to soil showed a trend of increased FC over time at deeper layers. The trend was similar for all soil layers for three years except for the 40-60 cm layer: averaged over three years, $24 \mathrm{Mg} \mathrm{ha}^{-1}$ treatment had the greatest effect.

Plant available water (PAW). All bentonite amendments significantly $(P<0.05)$ increased PAW compared with control in 0-40 cm layers (Fig. 2). Bentonite amendments had no effect in 40-60 cm layer. In 2013, 2014 and 2015, observed increases in PAW were up to 6\%,10\% and 10\%, respectively. Improvement in PAW ranged from $1-9 \%$ for the $0-10 \mathrm{~cm}$ layer, from $4-10 \%$ for $10-20 \mathrm{~cm}$, from $1-9 \%$ for $20-40 \mathrm{~cm}$ and from $1-9 \%$ for the 40-60 cm layers. The amendment effect showed a trend for increasing effect over time. The trend for all layers was similar to FC from 2013-2014: averaged over three years, the treatment with $24 \mathrm{mg} \mathrm{ha}^{-1}$ bentonite had the largest effect.

Emergence rate (ER). The effect of bentonite on ER in 2014 and 2015 is presented in Fig. 3; emergence data from the first three years of the same experiment were presented in our previous paper ${ }^{31}$. The present additional data combined with our earlier data now show that bentonite and interaction of bentonite treatment and time had a significant $(P<0.05)$ effect for ER over five years and more importantly, that there was greater effect in later years. The increase in ER for all bentonite treatments over the control with no bentonite ranged from $2-16 \%$ and $2-18 \%$ in 2014 and 2015, respectively. 

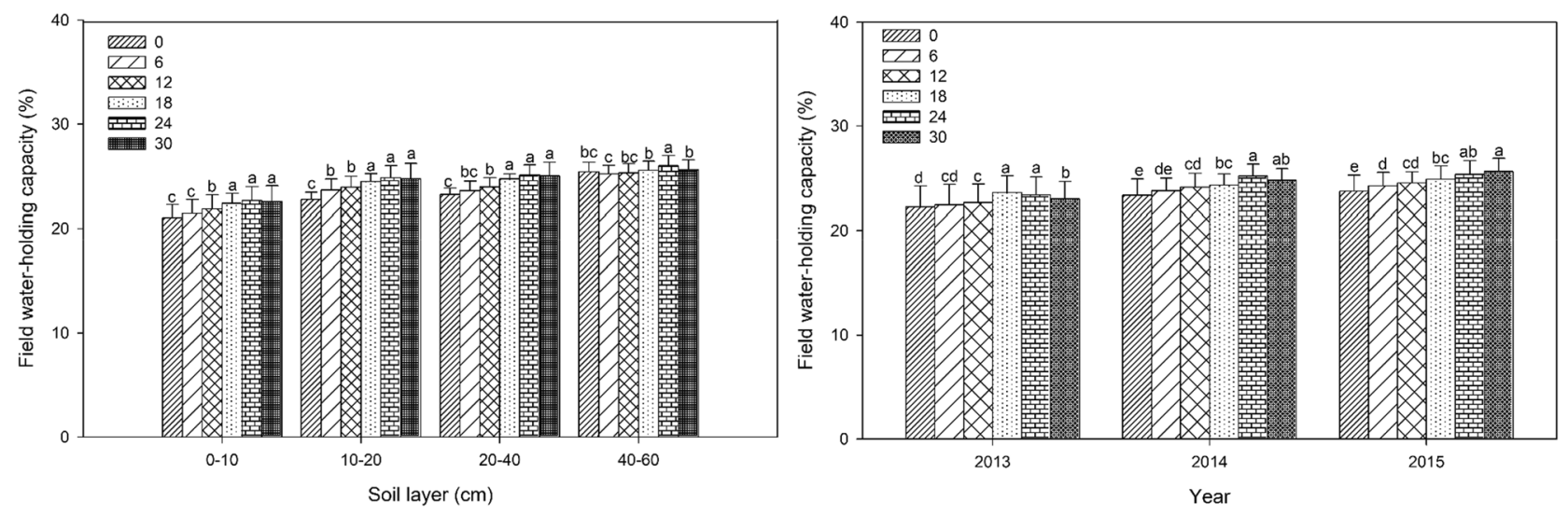

Figure 1. Field water-holding capacity for different rates of bentonite measured at $90 \mathrm{~d}$ after sowing in the 0-60 cm soil layer from 2013 to 2015. Left panel: mean of 2013 to 2015 by soil layer; right panel: mean of $0-60 \mathrm{~cm}$ soil layer by year. Bars within the same year or the same layer and with the same letters are not significantly different at the 0.05 level of probability. Error bars are standard deviations.
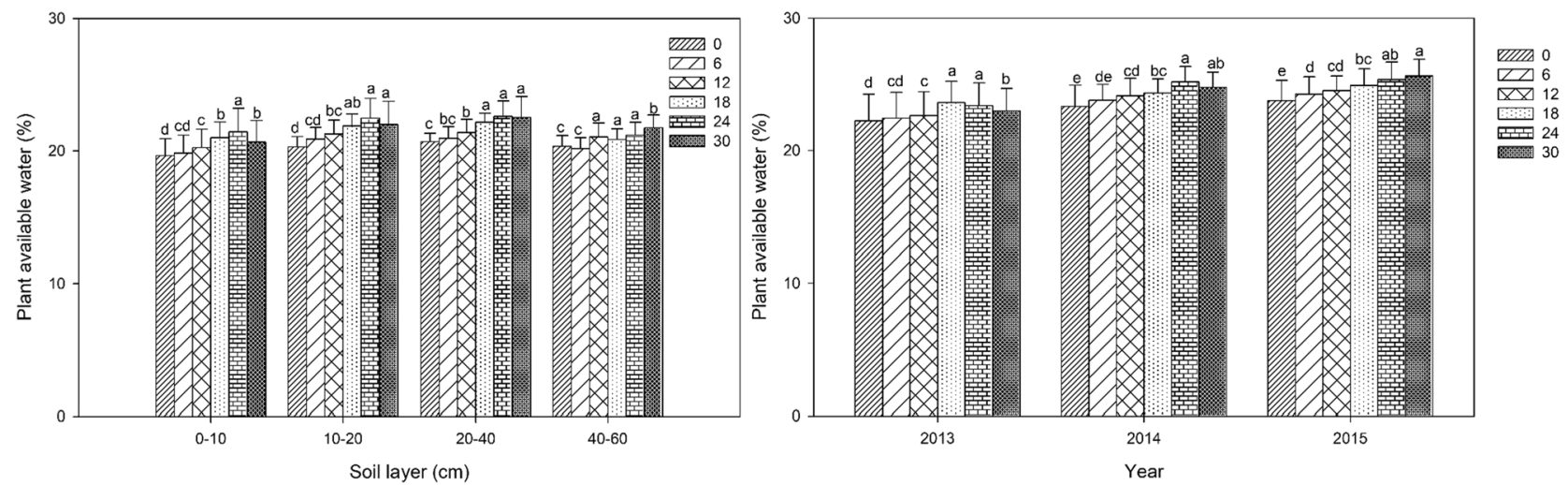

Figure 2. Plant available water with different rates of bentonite amendment at $90 \mathrm{~d}$ after sowing in the $0-60 \mathrm{~cm}$ soil layer from 2013-2015. Left panel: mean of 2013 to 2015 by soil layer; right panel: mean of 0-60 cm soil layer by year. Bars within the same year or the same layer and with the same letters are not significantly different at the 0.05 level of probability. Error bars are standard deviations.

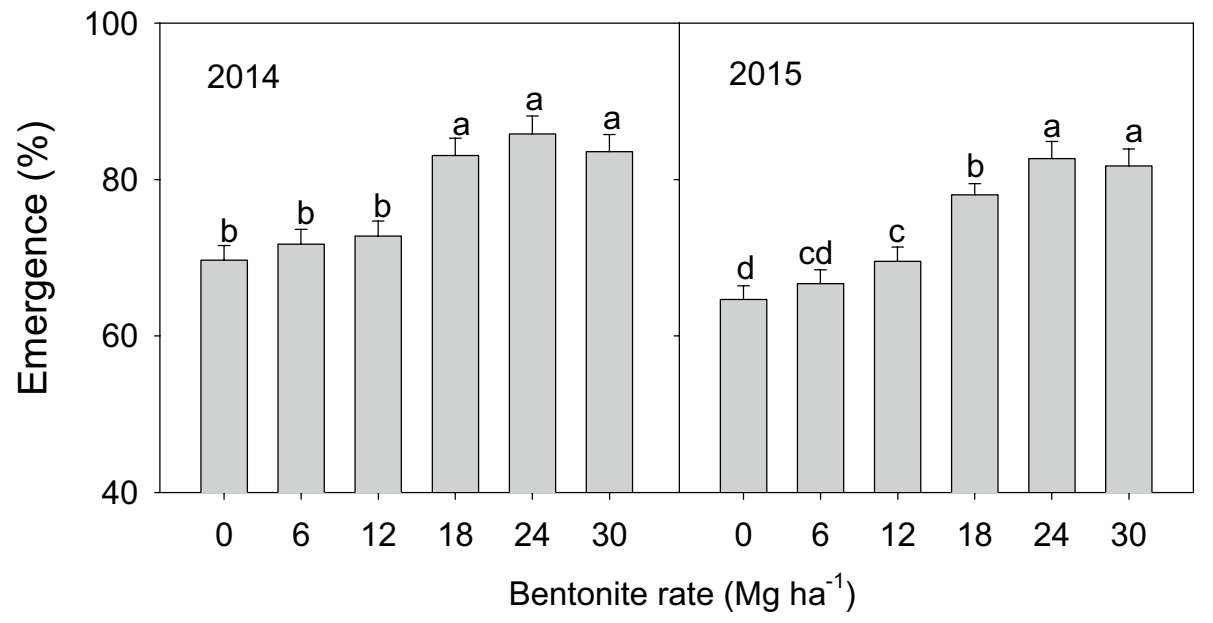

Figure 3. Millet emergence (\%) at 30 days after sowing with different rates of bentonite in 2014 and 2015. Bars within the same year and with the same letters are not significantly different at the 0.05 level of probability. Error bars are standard deviations. 


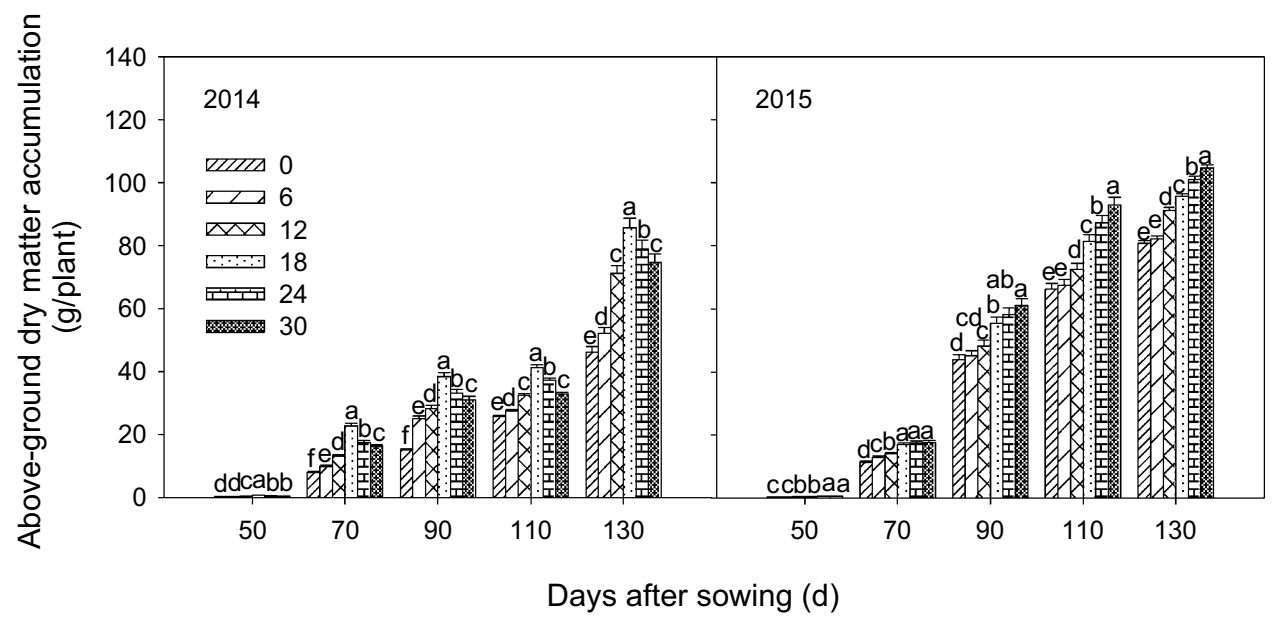

Figure 4. Above-ground dry matter accumulation with different rates of bentonite at different days after sowing in 2014 and 2015. Bars in the same year and with the same letter are not significantly different at the 0.05 level of probability. Error bars are standard deviations.

Aboveground dry matter (AGDM). AGDM data at different days after planting from the first three years of the same experiment were presented in our previous paper ${ }^{32}$. For all bentonite treatments, AGDM was significantly increased by up to $187 \%$ and $111 \%$ in 2014 and 2015 , respectively compared with the control without bentonite (Fig. 4). The greatest percentage differences among all treatments occurred at $70 \mathrm{~d}$ after sowing in the first four years; in 2015 the difference was greatest at $50 \mathrm{~d}$ after sowing, likely due to the very low rainfall over the growing season. In the first four years, 18 and $24 \mathrm{mg} \mathrm{ha}^{-1}$ treatment had significantly $(P<0.05)$ higher AGDM than the other treatments while, in 2015, the AGDM over growing season was the largest for $30 \mathrm{mg} \mathrm{ha}^{-1}$ treat- $^{-}$ ment.

Photosynthesis characteristics (Pn, Tr, SPAD, and WUE). Bentonite significantly $(P<0.05)$ increased $\mathrm{Pn}, \mathrm{Tr}, \mathrm{SPAD}$ and WUE compared to control without bentonite from 2013 to 2015 (Fig. 5). Increases in Pn, Tr, SPAD and WUE were 3-32\%, 2-21\%, 1-15\% and 0-13\% compared with control without bentonite in all three years. All of the photosynthesis parameters showed a similar trend: in the third year (2013), $18 \mathrm{mg} \mathrm{ha}^{-1}$ bentonite had the greatest effect; and averaged over three years, $24 \mathrm{mg} \mathrm{ha}^{-1}$ bentonite had the greatest effect.

Grain quality. Grain protein, fat and fiber all increased with increasing bentonite rates in all five years (Fig. 6). Exceptions were in 2014 when the effect on grain protein was not significant and in the last three years, when there were no significant $(P>0.05)$ differences in grain fiber between 0 and $6 \mathrm{mg} \mathrm{ha}^{-1}$ bentonite. In the first three years, 18 and $24 \mathrm{mg} \mathrm{ha}^{-1}$ bentonite had the highest grain protein, fat and fiber content while in last the two years, 24 and $30 \mathrm{mg} \mathrm{ha}^{-1}$ bentonite had the highest grain protein, fat and fiber content. The grain protein, fat and fiber content increased by up to $28 \%, 10 \%$ and $20 \%$ respectively over the control without bentonite from 2011 to 2015.

Correlations among soil and crop parameters. There were highly significantly positive correlations among emergence rate, soil available water, field water capacity, photosynthesis parameters and grain quality parameters. Correlation coefficients ranged from 0.91 to 0.99 (Table 5).

\section{Discussion}

Field water holding capacity (FC) and plant available water (PAW). Millet heading stage appeared around $90 \mathrm{~d}$ after sowing, and large quantities of soil water and nutrients were required to meet vigorous growth demands of millet at this stage. When mixed into soil by tillage, polymer superabsorbent soil amendments can quickly absorb a large amount of water under sufficient water conditions, and then slowly release water for plant uptake under drought conditions ${ }^{43,44}$. Our study showed that the effect of bentonite extended deeper into the 0-40 cm layer with increasing time since initial application, likely due to more uniform mixing with annual tillage. Our results indicated that addition of bentonite increased retention of soil water and soil available water up to $12 \%$ and $10 \%$ respectively in the surface soil layers (Figs. 1 and 2), which would be available for crop use. This can improve crop production in semi-arid regions with limited rainfall, and alleviate the need for irrigation. The bentonite can absorb a large amount of water and hold it within the bentonite crystal structure ${ }^{45}$. In addition, the bentonite $(75 \mu \mathrm{m}$ particle size) was mixed intimately with sandy soil and created smaller pores which can retain more water. Suzuki and Noble also reported that the application of bentonite amendment to a sandy soil over two years increased the available water for crop growth which was attributed to an increase in porosity and altered pore size distribution ${ }^{46}$. Our result agreed with a report that when clay with different aggregate sizes was added to a sandy soil simulating clay delving from a clay rich subsoil, plant available water and water reten- 


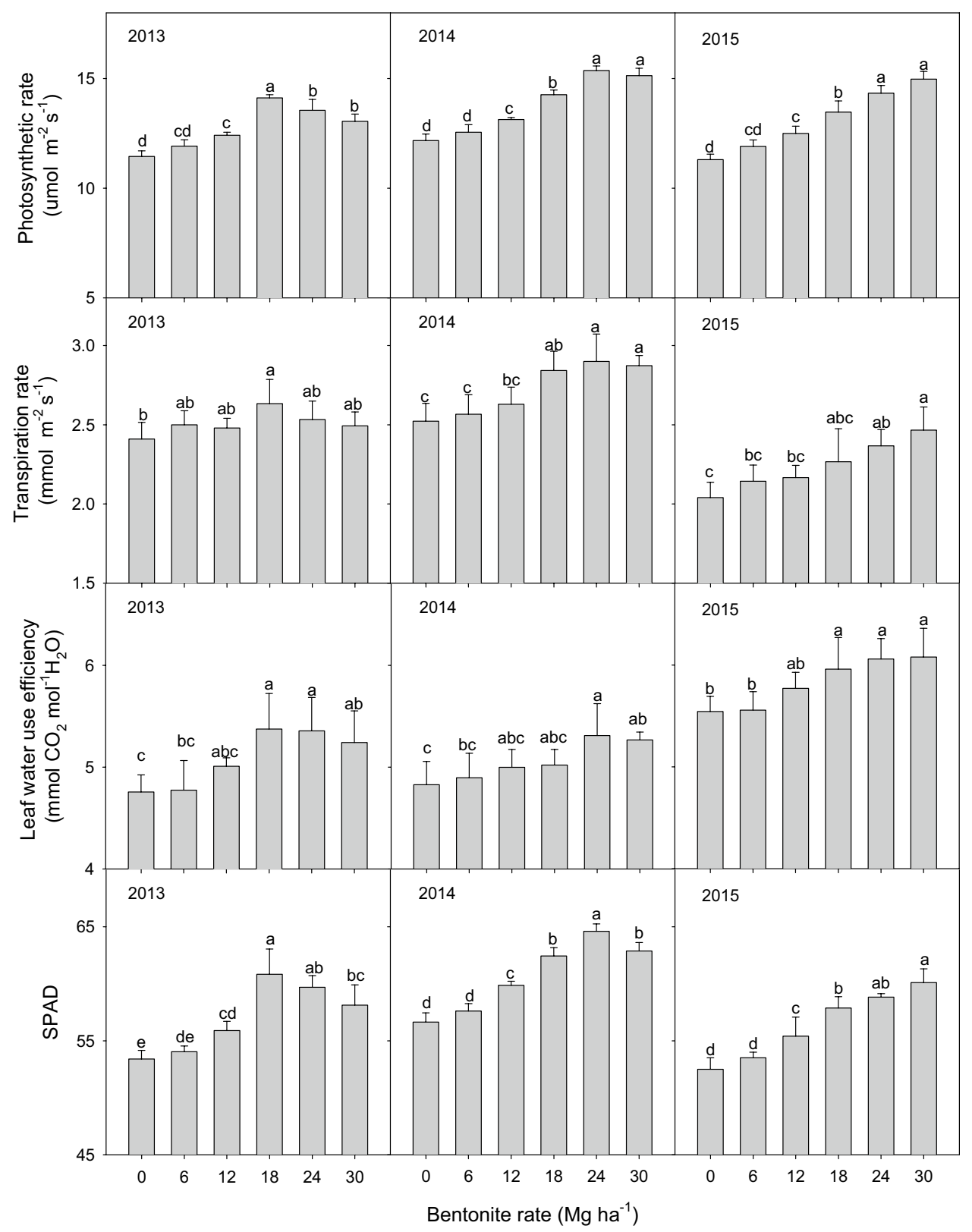

Figure 5. Millet photosynthesis parameters with different rates of bentonite at $90 \mathrm{~d}$ after sowing from 2013 to 2015. Bars within the same photosynthesis parameter, same year and with the same letters are not significantly different at the 0.05 level of probability. Error bars are standard deviations.

tion capacity increased in proportion to the amount of clay added, and in particular, application of smaller clay aggregates $(\leq 6 \mathrm{~mm})$ had a greater effect ${ }^{47}$. Another study also reported that available water content increased by $6.7-13.3 \%$ in calcareous sandy soils after bentonite application ${ }^{48}$. In contrast, another study observed that water absorbing soil amendments had a negative effect on crop performance for maize, possibly because they held the water too tightly, limiting water uptake by crops under limited water conditions ${ }^{49}$. The disagreement among studies may due to differences in amendment type and application rate. The mechanism by which water is held by bentonite, a natural clay material, and synthetic superabsorbent polymers is very different which results in different optimum application rates, and different water release characteristics. A previous seven-year study reported that a single application of bentonite-humic acid $\left(20 \mathrm{mg} \mathrm{ha}^{-1}\right)$ to sandy soil increased soil water storage and maize yield in a semi-arid region, and it had the greatest effect in the first five years following application ${ }^{50}$. Another study reported that large amount of superabsorbent resin quickly absorbed water, but the water was tightly held by the molecular structure and could not be released fast enough for plant use ${ }^{51}$. Other reasons may be due to differences in soil and external environmental factors such as potential evapo-transpiration. 


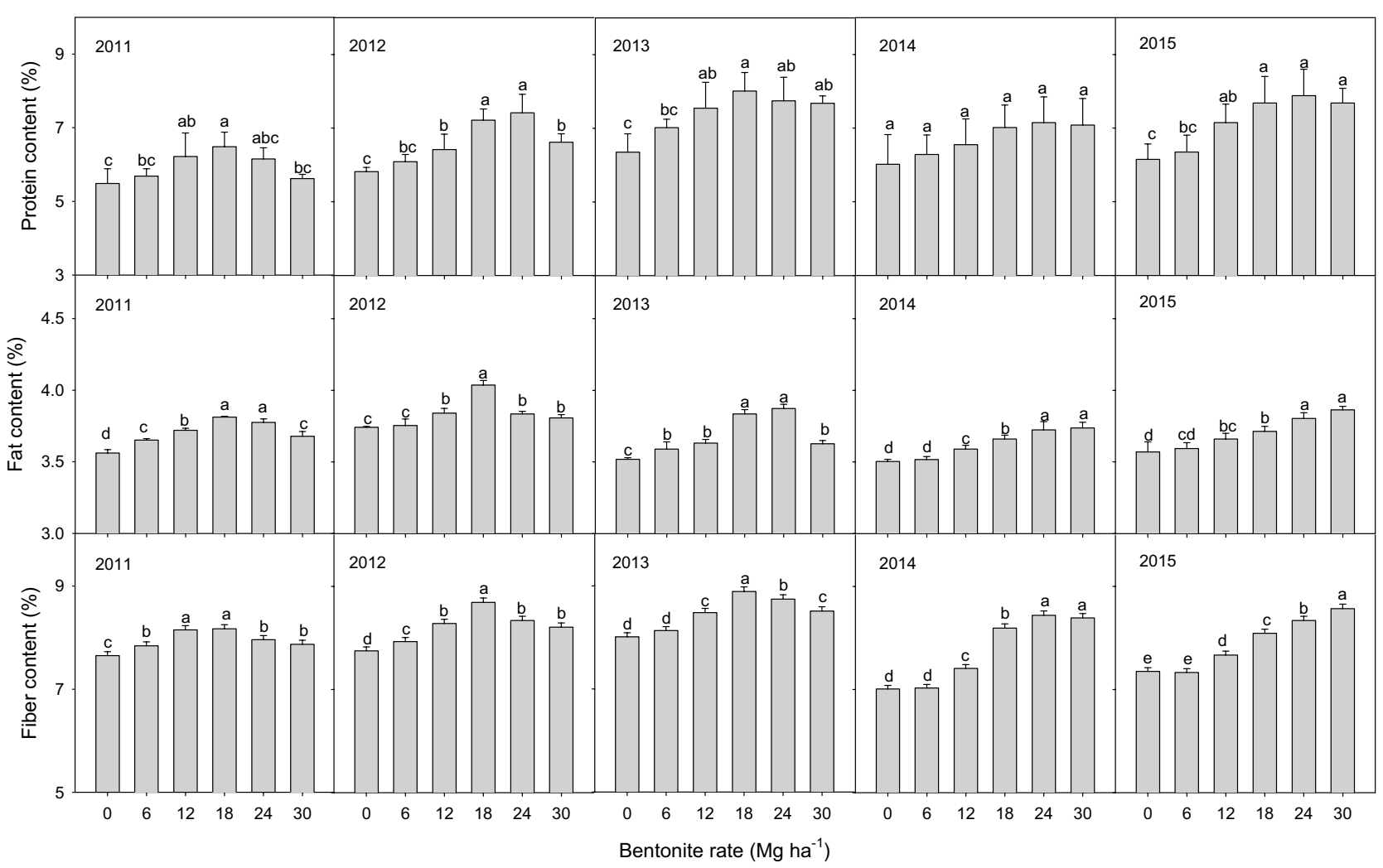

Figure 6. Millet grain quality parameters with different rates of bentonite from 2011 to 2015 . Bars within the same grain quality parameter, same year and with the same letters are not significantly different at the 0.05 level of probability. Error bars are standard deviations.

\begin{tabular}{|c|c|c|c|c|c|c|c|c|c|c|c|}
\hline Index & Emergence rate & $\begin{array}{l}\text { Above-ground dry } \\
\text { matter }\end{array}$ & SPAD & Pn & $\mathrm{Tr}$ & WUE & Soil available water & Field water capacity & Fat & Protein & Fiber \\
\hline Emergence rate & 1 & & & & & & & & & & \\
\hline $\begin{array}{l}\text { Above-ground dry } \\
\text { matter }\end{array}$ & $0.956^{* *}$ & 1 & & & & & & & & & \\
\hline SPAD & $0.993^{* *}$ & $0.977^{* *}$ & 1 & & & & & & & & \\
\hline Pn & $0.993^{* *}$ & $0.948^{* *}$ & $0.991^{\star *}$ & 1 & & & & & & & \\
\hline $\operatorname{Tr}$ & $0.987^{* *}$ & $0.947^{* *}$ & $0.981^{\star *}$ & $0.993^{* *}$ & 1 & & & & & & \\
\hline WUE & $0.990^{* *}$ & $0.948^{\star *}$ & $0.992^{\star *}$ & $0.995^{* *}$ & $0.976^{* *}$ & 1 & & & & & \\
\hline Soil available water & $0.986^{* *}$ & $0.967^{* *}$ & $0.985^{* *}$ & $0.978^{* *}$ & $0.966^{* *}$ & $0.982^{* *}$ & 1 & & & & \\
\hline Field water capacity & $0.984^{\star *}$ & $0.958^{* *}$ & $0.985^{* *}$ & $0.993^{* *}$ & $0.989^{* *}$ & $0.986^{* \star}$ & $0.986^{* *}$ & 1 & & & \\
\hline Fat & $0.956^{* *}$ & $0.993^{* *}$ & $0.971^{* *}$ & $0.935^{\star *}$ & $0.933^{* *}$ & $0.938^{* *}$ & $0.965^{* *}$ & $0.940^{* *}$ & 1 & & \\
\hline Protein & $0.934^{* *}$ & $0.995^{* *}$ & $0.958^{* *}$ & $0.920^{* *}$ & $0.914^{* *}$ & $0.926^{* *}$ & $0.960^{* *}$ & $0.937^{* *}$ & $0.991^{* *}$ & 1 & \\
\hline Fiber & $0.969^{* *}$ & $0.992^{* *}$ & $0.990^{* *}$ & $0.967^{* *}$ & $0.959^{* *}$ & $0.969^{* *}$ & $0.964^{* *}$ & $0.963^{* *}$ & $0.982^{* *}$ & $0.977^{* *}$ & 1 \\
\hline
\end{tabular}

Table 5. Correlation among all the parameters. ${ }^{\star \star}$ Significant at 0.01 level. Pn: net photosynthetic rate; Tr: transpiration rate; SPAD: leaf soil plant analysis development; WUE: leaf water use efficiency.

Millet growth and photosynthesis. The water stored in the soil before sowing and during the growing season plays an important role in crop production under limited water supply ${ }^{52}$. Insufficient stand establishment of crop is a major problem in the region along the Great Wall in Inner Mongolia in northern China which is a semi-arid area, and is a critical factor affecting crop yield ${ }^{53}$. Our data showed that bentonite amendment improved millet emergence rate (ER), AGDM at different days after sowing from 2011 to 2015 and photosynthesis parameters at $90 \mathrm{~d}$ after sowing (Pn, Tr, SPAD and WUE) (Figs. 3-5) from 2013 to 2015. This is comparable to other research that showed application of superabsorbent polymer significantly improved photosynthesis characteristics ${ }^{54}$, maize yield and total dry matter under drought stress conditions ${ }^{55}$. We attributed this to improved soil water storage and availability of nutrients for crop growth by retaining limited rainfall and reducing loss of water from the soil ${ }^{56}$, thereby alleviating the drought stress in the crop. In addition, the application of bentonite with calcium, magnesium and potassium $\left(5,10,20,40 \mathrm{mg} \mathrm{ha}^{-1}\right)$ could increase plant biomass by increasing cation exchange capacity (CEC) and making more exchange sites available to hold plant nutrients 
for plant growth ${ }^{57}$. Nutrient retention by bentonite might also contribute to improvements in crop performance, but our experiment did not address this aspect. In our research, $\mathrm{K}, \mathrm{mg}$ and Fe contained in the bentonite could contribute to increased crop growth, and improve photosynthesis, and thus enhance AGDM accumulation. Magnesium is major element in chlorophyll and some of the observed photosynthesis response to bentonite might be a result of additional magnesium in the bentonite. The effects of bentonite water absorbing properties, and potassium and micronutrients on crop growth parameters are confounded in this experiment; further research is needed to separate the soil water holding aspects of bentonite from the chemical effects of potassium and other micronutrients contained within the bentonite. Previous studies showed that drought conditions have a negative effect on photosynthesis processes which affected carbon assimilation and growth by closure of plant leaf stomates and reduced permeability of mesophyll cells ${ }^{15,58}$.

Combining our published results on ER and AGDM from the first three years ${ }^{34,35}$ and the present results from the latter two years for the same experiment, it was evident that the amendment effect on millet emergence rate increased with time, and the photosynthesis characteristics and emergence rate had similar trends. These may be due to improvement in soil structure by bentonite with time as bentonite is stable in soil whereas some other synthetic superabsorbent polymer soil amendments break down over time. Also this may be due to the capacity of bentonite to intercalate fixed soil carbon and volatile groups over time by metal oxides, establishing a microbial and nutrient reservoir ${ }^{59}$. The improvement in AGDM by the amendments was greatest during the early growing season when millet was growing rapidly, the demand for water was high and rainfall was low.

Grain quality. Millet is a tropical cereal grain used for forage and food, and is very diverse in terms of grain structure and chemical composition. It has been cultivated to produce traditional products such as porridges, flatbreads and beers ${ }^{60}$. In this study, the bentonite increased grain protein, fat and fiber content in all five years (Fig. 6) which would improve the grain quality for the above food products. This is similar to the results of another study that bentonite amendments can improve sugar beet quality and increase sugar beet yield ${ }^{61}$. The amended soil retained larger amounts of water and nutrients than soil without amendment. This allows the absorbed water and nutrients to be held for a longer time and used by the crop when drought occurs thereby improving crop performance ${ }^{62,63}$. Grain protein for all rates of bentonite was significantly $(P<0.05)$ higher than the control without bentonite in all five years except for 2014. This might be explained by more even rainfall throughout the 2014 growing season: the positive effect of the amendments is derived from their ability to hold water during periods of intermittent rainfall, but under even and sufficient rainfall, this benefit is not realized.

The combined effect of improved yield and bentonite cost was reported in our previous publication ${ }^{31}$. Compared with control without bentonite, $6,12,18,24$ and $30 \mathrm{mg} \mathrm{ha}^{-1}$ bentonite increased total grain yield over five years by $614,1795,3528,3613$ and $3041 \mathrm{~kg} \mathrm{ha}^{-1}$ respectively, and based on a bentonite cost in China of 63 US \$ $\mathrm{Mg}^{-1}$, improved respective total net return over five years by $64,536,1406,1089$ and $300 \mathrm{US} \$ \mathrm{ha}^{-1}$.

In semi-arid and arid areas, soil is characterized by low water-holding capacity, low fertility and low production. Some studies found that water absorbing soil amendments reduced soil erosion, improved soil nutrients and water-holding capacity and available water and nutrients for crop uptake, and thereby reduced the environmental pollution and enhanced soil productivity ${ }^{64,65}$. Our results suggest that bentonite soil amendments can also improve crop performance attributes and contribute to sustainable agricultural development in arid and semi-arid regions.

\section{Conclusions}

Bentonite amendments increased field water holding capacity and plant available water at $90 \mathrm{~d}$ after sowing in all three years (2013-2015). Bentonite significantly $(P<0.05)$ increased millet emergence rate, aboveground dry matter accumulation, photosynthesis parameters (Pn, Tr, SPAD and WUE) and grain quality parameters (protein, fat and fiber). The $24 \mathrm{mg} \mathrm{ha}^{-1}$ bentonite amendment had the greatest effect on crop performance parameters averaged over five years, and on photosynthesis parameters averaged over the three years (2013-2015) that they were measured; the $18 \mathrm{mg} \mathrm{ha}^{-1}$ bentonite amendment rate had the greatest effect on grain quality. Bentonite, which is plentiful in China, is a stable mineral requiring only one application and therefore has a distinct advantage over synthetic water absorbing polymers which break down over several years and must be periodically reapplied to maintain their effect. Thus, application of bentonite may be a practical and effective strategy for improving millet production in semi-arid regions in northern China or the regions with a similar environment.

Received: 20 April 2020; Accepted: 6 October 2020

Published online: 26 October 2020

\section{References}

1. Waggoner, P. E. Agriculture and a climate changed by more carbon dioxide. In Changing Climate: Report of the Carbon Dioxide Assessment Committee (ed. National Research Council (NRC)) 383-418 (National Academy Press, Washington, DC, 1983). https ://doi.org/10.1038/s41598-020-75350-9.

2. Shinozaki, K., Yamaguchi-Shinozaki, K. \& Seki, M. Regulatory network of gene expression in the drought and cold stress responses. J. Curr. Opin. Plant Biol. 6, 410-417 (2003).

3. Deng, X. et al. Improving agricultural water use efficiency in arid and semiarid areas of China. J. Agric. Water Manag. 80, 23-40 (2006).

4. Hussain, M. et al. Improving drought tolerance by exogenous application of glycinebetaine and salicylic acid in sunflower. J. Agron. Crop Sci. 194, 193-199 (2008).

5. Wang, W., Vinocur, B. \& Altman, A. Plant responses to drought, salinity and extreme temperatures: Towards genetic engineering for stress tolerance. J. Planta. 218, 1-14 (2003).

6. Bartels, D. \& Sunkar, R. Drought and salt tolerance in plants. J. Crit. Rev. Plant Sci. 24, 23-58 (2005). 
7. Rost, S. et al. Global potential to increase crop production through water management in rainfed agriculture. J. Environ. Res. Lett. 4, 1-9 (2009).

8. Miflin, B. Crop improvement in the 21st century. J Exp Bot. 51, 1-8 (2000).

9. Islam, M. R. et al. Impact of water-saving superabsorbent polymer on oat (Avena spp.) yield and quality in an arid sandy soil. J. Sci. Res. Essays. 6, 720-728 (2011).

10. Lu, H. et al. Earliest domestication of common millet (Panicum miliaceum) in East Asia extended to 10000 years ago. J. Proc. Natl. Acad. Sci. 106, 7367-7372 (2009).

11. Anonymous. Plant area of millet in China in 2017. Available from: https://data.chinabaogao.com/nonglinmuyu/2019/0R43PA2019 .html (2019).

12. Tolk, J., Howell, T. \& Evett, S. Effect of mulch, irrigation, and soil type on water use and yield of maize. J. Soil Tilll Res. 50, 137-147 (1999).

13. Panda, R., Behera, S. \& Kashyap, P. Effective management of irrigation water for maize under stressed conditions. J. Agric. Water Manag. 66, 181-203 (2004).

14. Cattivelli, L. et al. Drought tolerance improvement in crop plants: An integrated view from breeding to genomics. J. Field Crop Res. 105, 1-14 (2008).

15. Chaves, M. M. et al. How plants cope with water stress in the field? Photosynthesis and growth. J. Ann. Bot.-Lond. 89, 907-916 (2002).

16. Xu, C. et al. Effect of biochar amendment on yield and photosynthesis of peanut on two types of soils. J. Environ. Sci. Pollut. R. 22, 6112-6125 (2015)

17. Shah, N. \& Paulsen, G. Interaction of drought and high temperature on photosynthesis and grain-filling of wheat. J. Plant Soil. 257, 219-226 (2003).

18. Soda, W. et al. Co-composting of acid waste bentonites and their effects on soil properties and crop biomass. J. Environ. Qual. 35, 2293-2301 (2006).

19. Guiwei, Q., De Varennes, A. \& Cunha-Queda, C. Remediation of a mine soil with insoluble polyacrylate polymers enhances soil quality and plant growth. J. Soil Use Manag. 24, 350-356 (2008).

20. Hüttermann, A., Orikiriza, L. J. B. \& Agaba, H. Application of superabsorbent polymers for improving the ecological chemistry of degraded or polluted lands. J. Clean Soil. Air. Water. 37, 517-526 (2009).

21. Narjary, B. et al. Water availability in different soils in relation to hydrogel application. J. Geoderma 187, 94-101 (2012).

22. Arbona, V. et al. Hydrogel substrate amendment alleviates drought effects on young citrus plants. J. Plant Soil. 270, 73-82 (2005).

23. Wang, Y. et al. Influences of Millet-Peanut intercropping on photosynthetic characteristics and yield of Millet. J. Agric. Sci. Technol. 22, 153-165 (2020).

24. Gao, H. et al. Diurnal change of photosynthetic characteristics and response tonight intensity of seven ornamental grasses. J. Acta Prataculturae Sinica 19, 87-93 (2010).

25. Yordanov, I., Velikova, V. \& Tsonev, T. Plant responses to drought, acclimation, and stress tolerance. J. Photosynthetica 38, 171-186 (2000).

26. Yangwei, P. \& Yan, S. Resources characteristics and market situation of bentonites at home and Abroad. J. Metal Mine. 95-99, 105 (2012).

27. Fraenkel-Conrat, H., Singer, B. \& Tsugita, A. Purification of viral RNA by means of bentonite. J. Virol. 14, 54-58 (1961).

28. Lopez-Fernandez M, et al. Microbial community changes induced by uranyl nitrate in bentonite clay microcosms. In 16 th International Clay Conference (ICC). Granada, Spain (2017).

29. Bentahar, S. et al. Removal of a cationic dye from aqueous solution by natural clay. J. Groundw. Sustain. Devel. 6, 255-262 (2018).

30. De Castro, M. L. F. A. et al. Adsorption of Methylene Blue dye and Cu(II) ions on EDTA-modified bentonite: Isotherm, kinetic and thermodynamic studies. J. Sustain. Environ. Res. 28, 197-205 (2018).

31. Mi, J. et al. Effect of bentonite amendment on soil hydraulic parameters and millet crop performance in a semi-arid region. J. Field Crop Res. 212, 107-114 (2017).

32. Hall, D. J. M. et al. Claying and deep ripping can increase crop yields and profits on water repellent sands with marginal fertility in southern Western Australia. J. Aust. J. Soil Res. 48, 178-187 (2010).

33. Shi, Y., Chen, X. \& Shen, S. Mechanisms of organic cementing soil aggregate formation and its theoretical models. J. Chin. J. Appl. Ecol. 13, 1495-1498 (2002)

34. Mi, J. et al. Effect of sandy soil amendment on Dry-farmland water-conserving characteristic and millet seeding growth. J. Irrigat. Drain. 23, 92-96 (2015).

35. Mi, J. et al. Effects of sandy soil amendment on soil moisture and growth status of millet with rainfed sandy soil in a semi-arid region. J. Adv. Mater. Res. 1092-1093, 1234-1242 (2015).

36. Jiang, P. et al. Principles and experimental verification of capillary suction method for fast measurement of field capacity. J. Trans. CSAE. 22, 1-5 (2006).

37. Andrenelli, M. et al. Field application of pelletized biochar: Short term effect on the hydrological properties of a silty clay loam soil. J. Agric. Water Manag. 163, 190-196 (2016).

38. Jones, J. Jr. Kjeldahl Method for Nitrogen Determination (Micro-Macro Publishing, Athens, 1991).

39. Nielsen, S. S. Food Analysis (Aspen Publishers Inc, New York, 1998).

40. Ganzler, K., Salgo, A. \& Valkó, K. Microwave extraction: A novel sample preparation method for chromatography. J. Chromatogr. A 371, 299-306 (1986).

41. Min D B, Steenson D, Crude fat analysis. In Food Analysis. Vol. 2. New York: Kluwer Academic/Plenum Publishers. 113-131 (1998).

42. Möller, J. Comparing Methods for Fibre Determination in Food and Feed, Vol. 1026712 (The Association of American Feed Control Officials, West Lafayette, 2014).

43. Bakass, M., Mokhlisse, A. \& Lallemant, M. Absorption and desorption of liquid water by a superabsorbent polyelectrolyte: Role of polymer on the capacity for absorption of a ground. J Appl Polym. Sci. 82, 1541-1548 (2001).

44. Yu, J. et al. Superabsorbents and semiarid soil properties affecting water absorption. J. Soil. Sci. Soc. Am. J. 75, 2305-2313 (2011).

45. Sun, Z. et al. Effect of ion-type and concentration on water-retention capacity of bentonite used in geosynthetic clay liner. J. Chin. Ceram. Soc. 38, 1826-1831 (2010).

46. Suzuki, S. et al. Improvement in water-holding capacity and structural stability of a sandy soil in Northeast Thailand. J. Arid Land Res. Manag. 21, 37-49 (2007).

47. Betti, G. et al. Size of subsoil clods affects soil-water availability in sand-clay mixtures. J. Soil Res. 54, 276-290 (2016).

48. Al-Omran, A. et al. Impact of natural deposits of Saudi Arabia on selected physical properties of calcareous sandy soil. J. Dirasa Agric Sci. 29, 285-294 (2002).

49. Tan, G. et al. Effect of super absorbent resin on the rate of maize emergence and soil moisture. J. Jilin Agric. Sci. 30, 26-27 (2004).

50. Zhou, L. et al. Effect of bentonite-humic acid application on the improvement of soil structure and maize yield in a sandy soil of a semi-arid region. J. Geoderma. 338, 269-280 (2019).

51. Fang, S. et al. Synthesis of chitosan derivative graft acrylic acid superabsorbent polymers and its application as water retaining agent. J. Int. J. Biol. Macromol. 115, 754-761 (2018).

52. Zhang, X. et al. Dry matter, harvest index, grain yield and water use efficiency as affected by water supply in winter wheat. J. Irrigation Sci. 27, 1-10 (2008). 
53. Giri, G. S. \& Schillinger, W. F. Seed priming winter wheat for germination, emergence, and yield. J. Crop Sci. 43, 2135-2141 (2003).

54. Jamnická, G. et al. The soil hydrogel improved photosynthetic performance of beech seedlings treated under drought. J. Plant Soil Environ. 59, 446-451 (2013).

55. Islam, M. R. et al. A lysimeter study of nitrate leaching, optimum fertilisation rate and growth responses of corn (Zea mays L.) following soil amendment with water-saving super-absorbent polymer. J. Sci/ Food Agric. 91, 1990-1997 (2011).

56. Tahir, S. \& Marschner, P. Clay amendment to sandy soil-Effect of clay concentration and ped size on nutrient dynamics after residue addition. J. Soils Sediments 16, 2072-2080 (2016).

57. Croker, J. et al. Effects of recycled bentonite addition on soil properties, plant growth and nutrient uptake in a tropical sandy soil. J. Plant Soil. 267, 155-163 (2004).

58. Brix, H. The effect of water stress on the rates of photosynthesis and respiration in tomato plants and loblolly pine seedlings. J. Physiol. Plantarum. 15, 10-20 (1962).

59. Wang, L. et al. Progress in researches on effect of iron promoting accumulation of soil organic carbon. J. Acta Pedologica Sinica 55, 1041-1050 (2018).

60. Taylor, J. R. N. \& Duodu, K. G. Sorghum and millets: Grain-quality characteristics and management of quality requirements. In Cereal Grains (2nd edn) (eds Batey, I. \& Miskelly, D.) 317-351 (Woodhead Publishing, Wrigley, Colin, 2017).

61. Abbas, M. et al. Effect of some soil amendments on yield and quality traits of sugar beet (Beta vulgaris L.) under water stress in sandy soil. J. Egypt. J. Agron. 40, 75-88 (2018).

62. Leila, K., Hassan, F. \& Pooran, G. Effects of different irrigation and superabsorbent levels on physio-morphological traits and forage yield of millet (Pennisetum americanum L.). J. Am. Euras. J. Agric. Environ. Sci. 13, 1043-1049 (2013).

63. Li, X. et al. Effects of super-absorbent polymers on a soil-wheat (Triticum aestivum L.) system in the field. J. Appl Soil Ecol. 73, 58-63 (2014).

64. Sojka, R. et al. Polyacrylamide in agriculture and environmental land management. J. Adv Agron. 92, 75-162 (2007).

65. Wang, A., Li, F. \& Yang, S. Effect of polyacrylamide application on runoff, erosion, and soil nutrient loss under simulated rainfall. J. Pedosphere. 21, 628-638 (2011).

\section{Acknowledgements}

The study was supported by the National Natural Science Foundation of China [Number 31160267]; the National Science and Technology Program No.12 [Number 2015BAD22B04-02]; Scientific and Technological Innovation Team of Inner Mongolia; Multi-grain Engineering and Technology Center of Inner Mongolia; the Scientific Research Foundation of Inner Mongolia Agricultural University (NDYB2018-29); and MOE-AAFC PhD Research Program sponsored by Ministry of Education of the People's Republic of China and Agriculture and Agri-Food Canada.

\section{Author contributions}

J.M. and J.L, conceived and designed the experiment; E.G.G. contributed to analysis and interpretation of this work, and revising this paper for intellectual content; S.X. performed the experiment; N.B.M. analyzed the data and revised the manuscript; J.M. performed the experiment, and wrote and final the manuscript. All authors have reviewed this manuscript.

\section{Competing interests}

The authors declare no competing interests.

\section{Additional information}

Correspondence and requests for materials should be addressed to J.L.

Reprints and permissions information is available at www.nature.com/reprints.

Publisher's note Springer Nature remains neutral with regard to jurisdictional claims in published maps and institutional affiliations.

(c) (i) Open Access This article is licensed under a Creative Commons Attribution 4.0 International License, which permits use, sharing, adaptation, distribution and reproduction in any medium or format, as long as you give appropriate credit to the original author(s) and the source, provide a link to the Creative Commons licence, and indicate if changes were made. The images or other third party material in this article are included in the article's Creative Commons licence, unless indicated otherwise in a credit line to the material. If material is not included in the article's Creative Commons licence and your intended use is not permitted by statutory regulation or exceeds the permitted use, you will need to obtain permission directly from the copyright holder. To view a copy of this licence, visit http://creativecommons.org/licenses/by/4.0/.

(c) The Author(s) 2020 